\title{
Validating the self-reported annual monitoring grid for the 2007 Caribbean Community Declaration of Port-of-Spain on noncommunicable diseases
}

\author{
T. Alafia Samuels, ${ }^{1}$ Madhuvanti M. Murphy, ${ }^{2}$ and Nigel Unwin ${ }^{3}$
}

Suggested citation

Samuels TA, Murphy MM, Unwin N. Validating the self-reported annual monitoring grid for the 2007 Caribbean Community Declaration of Port-of-Spain on noncommunicable diseases. Rev Panam Salud Publica. 2018;42:e189. https://doi.org/10.26633/RPSP.2018.189

\begin{abstract}
Objectives. In 2007, the Caribbean Community (CARICOM) convened the world's first-ever heads of government summit on noncommunicable diseases (NCDs) and issued the landmark Declaration of Port-of-Spain: Uniting to Stop the Epidemic of Chronic NCDs. Since then, ministry of health $(\mathrm{MoH})$ focal points in each country have self-reported annually on their NCD efforts, using a 26-indicator grid created to assess implementation of the Declaration. Our objective was to assess the validity of those grid responses, as compared to information from in-depth interviews and document reviews.

Methods. Seven national case studies on policy responses to the Declaration were undertaken in 2015. In-depth, semistructured interviews were conducted with stakeholders from multiple sectors, including the MoH. Policy documents were also identified and reviewed. The results from the 2015 case studies were compared to the $2014 \mathrm{MoH}$ focal point grid responses. Kappa statistics evaluated chance agreement.

Results. The information from the grid and from the case studies agreed closely. Out of a total of 182 indicators (26 each for seven countries), there was a lack of agreement on just 9 $(4.9 \%)$. All the differences were between policy statements and implementation. Except for physical activity, kappa statistics indicated that agreement was good to excellent for all the clusters of the grid and for the grid as a whole, but with wide confidence intervals.

Conclusions. In general, the monitoring grid accurately assessed the national situation, but with a possible tendency to overstate performance in some areas. These findings contributed to the design of a new, 50-indicator monitoring grid in 2016. Alongside these improvements, CARICOM countries face a substantial burden from having to complete many other required NCD reports, mainly for the Pan American Health Organization and the World Health Organization.
\end{abstract}

Keywords Noncommunicable diseases; public health surveillance; West Indies.

\footnotetext{
2 Faculty of Medical Sciences, Cave Hill campus, University of the West Indies, Bridgetown,

Barbados.

3 MRC Epidemiology Unit, University of Cambridge, Cambridge, United Kingdom.
} respondence to T. Alafia Samuels at alafia.samuels@ cavehill.uwi.edu or alafiasam@gmail.com
Governments have a primary role in creating health-promoting environments as an essential input for sustainable development $(1,2)$. In 2007, the Caribbean 
Community (CARICOM) convened the world's first-ever heads of government summit on noncommunicable diseases (NCDs) and issued the landmark Declaration of Port-of-Spain: Uniting to Stop the Epidemic of Chronic NCDs (3).

In 2014, CARICOM and the Pan American Health Organization/World Health Organization (PAHO/WHO), on behalf of the CARICOM member countries, commissioned a formal evaluation of country compliance with the mandates from the 2007 NCD Declaration. This evaluation was funded by the Canadian International Development Research Centre (4).

The overall objective was to evaluate, seven years on, the implementation of the 2007 Port-of-Spain Declaration, in order to learn lessons to accelerate its further implementation and to inform the attainment of the WHO's Global Monitoring Framework for NCDs. Adopted in 2013, the WHO Framework stemmed from the 2011 United Nations Political Declaration of the High-level Meeting of the General Assembly on the Prevention and Control of Non-communicable Diseases. Similarly, the 2030 Sustainable Development Goal \#3 aims to reduce the burden of NCDs through improvements in coverage and reduction of risk factors (5).

As described elsewhere (6), this formal evaluation had six research objectives. Objective 1 was to add to knowledge on the implementation of the Port-of-Spain Declaration by determining the extent to which the mandates in the Declaration were reported to have been implemented within the 20 CARICOM countries and territories. These 20 consist of 15 full members plus 5 associate members that are United Kingdom Overseas Territories.
The work to meet this evaluation's Objective 1 built on the existing system of annual monitoring of 26 progress indicators utilizing a grid developed in 2008 and first revised in 2010 (7). In each CARICOM member state, the NCD focal point in the ministry of health $(\mathrm{MoH})$ has reported to the University of the West Indies (UWI) annually on whether they had met, not met, or made progress towards meeting each of the Port-of-Spain Declaration mandates. This information has then been summarized by UWI in a color-coded grid. The completed grid has been presented each year to the annual meeting of the CARICOM ministers of health, and to the CARICOM Heads of Government.

The objective of this paper was to assess the validity of self-reported responses to the grid, as compared to in-depth interview data and document reviews. We report on the process and outcome of a second revision of the grid in 2016, and also on the number of NCD reports required from countries annually or every two, three, or five years by the World Health Organization, the Pan American Health Organization, the Caribbean Pubic Health Agency, and the UWI.

\section{METHODS}

\section{Validation of the grid used in 2008-2015}

Case studies on policy responses to the Declaration were undertaken between April 2015 and July 2015 in seven CARICOM member states: Antigua and Barbuda, Belize, British Virgin Islands, Grenada, Jamaica, Saint Kitts and Nevis, and Trinidad and Tobago. These seven member states were purposely selected to reflect large, medium, and small population sizes; mainland and island member states; full members and associate members; and countries with high or low levels of achievement of the Port-ofSpain Declaration mandates. A total of 76 in-depth, semistructured interviews were conducted with 80 stakeholders, from the ministry of health, other government ministries and agencies, civil society organizations, and the private sector. Interviews lasted 30 to 60 minutes, and the number of interviews in each country ranged from 7 to 12 (Table 1).

The interview schedule was structured around the major policy recommendations contained in the 2007 Port-of-Spain Declaration, and thus also covered the policy areas contained in the monitoring grid. In addition, the interviews covered policy on alcohol-related harm (not covered in the 2007 Declaration, or in the grid), as well as facilitators and hindrances to policy agenda-setting, development, and implementation.

All the 2015 interviews were recorded and transcribed verbatim. A framework analysis was undertaken in 2015 using Dedoose software (SocioCultural Research Consultants, University of California Los Angeles, Los Angeles, California, United States of America), which included identifying reported policy responses across the different domains found in the annual monitoring grid. A distinction was made between "policy statements" (such as written statements in policy documents, or statements made by policymakers) and "policy implementation," where key informants indicated that there was clear evidence that policies had been implemented and were active.

TABLE 1. Number of key informant interviews done in 2015, by country/territory and by sector, for national case studies on policy responses to the 2007 Caribbean Community Declaration of Port-of-Spain on noncommunicable diseases

\begin{tabular}{|c|c|c|c|c|c|c|}
\hline Country/Territory & Ministry of health & Other government & $\mathrm{NGO}^{\mathrm{a}}$ & Private & Academia & Total \\
\hline Antigua and Barbuda & 3 & 3 & 5 & - & - & 11 \\
\hline Belize & 4 & 3 & 4 & 1 & - & 12 \\
\hline British Virgin Islands & 5 & 3 & 3 & 1 & - & 12 \\
\hline Jamaica & 5 & 1 & 4 & 2 & 1 & 13 \\
\hline Saint Kitts and Nevis & 3 & 3 & - & 1 & - & 7 \\
\hline Trinidad and Tobago & 4 & 2 & 3 & 3 & - & 12 \\
\hline
\end{tabular}

Source: M. M. Murphy et al., based on the study results in article titled "Evaluating policy responses to promote diet and physical activity in seven Caribbean countries," in this supplement of the Revista Panamericana de Salud Pública/Pan American Journal of Public Health.

${ }^{\mathrm{a}} \mathrm{NGO}=$ nongovernmental organization. 
Findings from the 2015 interviews and document review were compared to responses that the respective $\mathrm{MoH}$ focal points had provided in the NCD grid 2014 reports (Table 2).

\section{Statistical analysis}

Agreement on the number of grid indicators met was assessed using the kappa statistic. This was done separately for each of the seven clusters (Table 2) of the grid, and for the grid as a whole. For each cluster of the grid, each country was given a score, which simply reflected the number of indicators met. Stata 13 statistical software (StataCorp, College Station, Texas, United States) was used to apply weighted kappa analysis, assessing the agreement between the scores reported by the NCD focal points and those derived from the analyses of the in-depth stakeholder interviews. Kappa values are reported with $95 \%$ confidence intervals based on the standard error reported by Stata and with $p$ values testing the null hypothesis of no agreement.

Ethical approval was received from the University of the West Indies/Ministry of Health Institutional Review Board in Barbados and from corresponding institutional review boards and/or ministries of health in the seven case study countries.

TABLE 2. Country implementation of mandates, in seven clusters, from the 2007 Caribbean Community Declaration of Port-ofSpain on noncommunicable diseases (NCDs), comparing ministry of health reports of 2014 vs. validation of response in 2015 from key informant interviews and document review ${ }^{\mathrm{a}}$

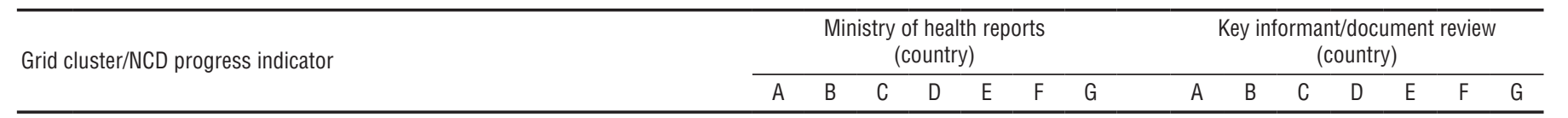

Commitment

NCD plan

NCD budget

NCD summit convened

Multisectoral NCD commission appointed and functional

Tobacco

FCTC ratified

Tobacco taxes $>50 \%$ sale price

Smoke-free indoor public places

Advertising, promotion, \& sponsorship bans

Nutrition

Multi-sector food \& nutrition plan implemented

Trans fat free food supply

Policy \& standards promoting healthy eating in schools implemented

Trade agreements utilized to meet national food security \& health goals

Mandatory labeling of packaged foods for nutrition content
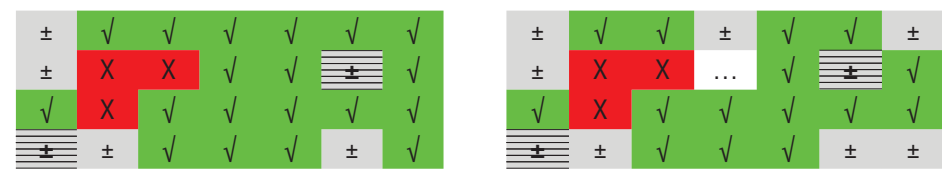

Physical activities

Mandatory PA in all grades in schools

Mandatory provision for PA in new housing developments

Ongoing, mass physical activity or new public PA spaces
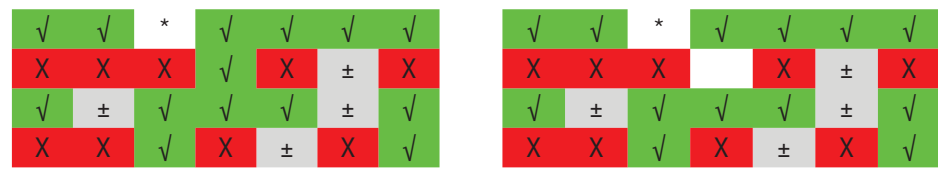

Education/Promotion

NCD communications plan

CWD multisectoral, multifocal celebrations

$\geq 50 \%$ of public and private institutions with physical activity \& healthy eating programs

$\geq 30$ days media broadcasts on NCD control/yr (risk factors and treatment)

Surveillance
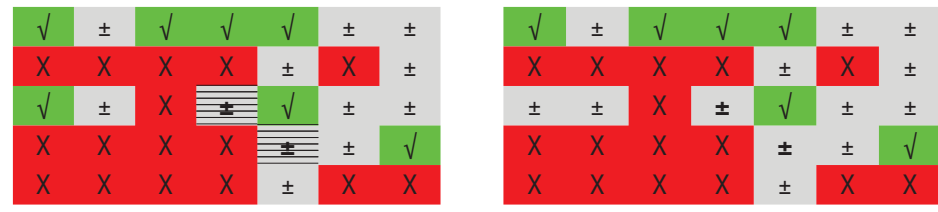

Surveillance: STEPS or equivalent survey

- Minimum data set reporting

- Global Youth Tobacco Survey

- Global School Health Survey
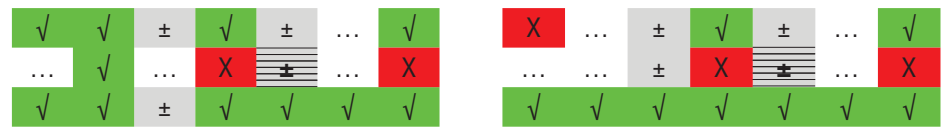

Treatment

Chronic care model/NCD treatment protocols in $\geq 50 \% \mathrm{PHC}$ facilities

QOC, CVD, or DM demonstration project

Source: George Alleyne Chronic Disease Research Centre, University of the West Indies

a Notes on the table: 1) Cells in the table in the columns under "Ministry of health reports" should be compared to cells under "Key Informant/document review" to determine where there are "downgrades" in status, based on the more objective data of the key informant interviews and document reviews. 2) The symbols and shading used in the table cells are: $\sqrt{ }=$ in place; $\pm=$ in process/partial; $X=$ not in place; ${ }^{*}=$ not applicable; $\ldots=$ no information. 3 ) The horizontal stripes in cells indicate a change from 2013 to 2014.4 ) Country A, B, C, D, E, F, and $G$ are the seven countries in which case studies were done. 5) The abbreviations used are: $C V D=$ cardiovascular disease; $C W D=$ Caribbean Wellness Day; DM $=$ diabetes mellitus;

FCTC = Framework Convention on Tobacco Control; PA = physical activity; $\mathrm{PHC}=$ primary health care; $\mathrm{QOC}=$ quality of care. 


\section{RESULTS}

\section{Validation of the 2008-2015 grid}

The results from the 2015 case studies agreed closely with the responses that the $\mathrm{MoH}$ focal points had given in 2014 to the NCD grid. Out of a total of 182 indicators (26 across seven countries), there was lack of agreement on just $9(4.9 \%)$. All the disagreements arose from the difference between policy statements and implementation (Table 2). For 17 of the 26 indicators, the self-reported grid data from 2014 aligned with the evidence collected in the seven countries from key informants and document reviews in 2015. For an additional 5 of the 26 indicators, one out of the seven case study countries had a change by one increment. For example, for one country, "multisectoral NCD commission appointed and functional" was downgraded from "yes" to "partial." In one case, there was an upgrade from "partial" to "yes." (In Table 2, differences in indicator status can be seen when comparing results from the middle of the table ("Response to grid") and the right side of the table ("Modified from $\mathrm{KI}$, doc review"). It is considered a downgrade where the specific indicator changes from "in place" to "in process / partial," "not in place," or "missing.")

Among the four remaining indicators, "mandatory PA [physical activity] in all grades in schools" was the least reliable indicator. While four countries had self-reported "yes," the review downgraded this to two countries. One country went from "yes" to "no," and in one country no evidence could be found to support the assertion.

Three other indicators had inadequate alignment. Having an NCD plan had two countries downgraded from "yes" to "partial." In one country, having a specific NCD budget and "tobacco taxes > $50 \%$ sale price" were downgraded from "in place" to "missing," since there was no data or key informant answers that supported this response.

\section{Validation by country}

Two of the seven countries-the highest performer and the lowest performer-had self-report 2014 grid responses that aligned exactly with data from the 2015 case-study key informants. One country was upgraded when we found evidence of partial compliance

TABLE 3. Agreement for the number of indicators for the 2007 Caribbean Community Declaration of Port-of-Spain on noncommunicable diseases, comparing ministry of health reports in 2014 of indicators having been met vs. validation of those responses from key informant interviews and document review in 2015

\begin{tabular}{lcc}
\hline Grid cluster (no. of indicators) & Weighted kappa $(95 \% \mathrm{Cl})^{\mathrm{a}}$ & $p$ value \\
\hline Commitment (4) & $0.59(0.12-1.00)$ & 0.007 \\
Tobacco control (4) & $0.81(0.28-1.00)$ & 0.001 \\
Nutrition (5) & $0.81(0.28-1.00)$ & 0.001 \\
Physical activity (3) & $0.30(-0.11-0.71)$ & 0.073 \\
Education/Promotion (4) & $0.87(0.30-1.00)$ & 0.001 \\
Surveillance (4) & $1.00(0.26-1.00)$ & 0.004 \\
Treatment (2) & $1.00(0.26-1.00)$ & 0.004 \\
\multicolumn{1}{c}{ All indicators (26) } & $0.63(0.18-1.00)$ & 0.003 \\
\hline
\end{tabular}

Source: Author NU, based on statistical analysis.

a The maximum value of the upper confidence interval $(\mathrm{CI})$ is limited to 1.00

with "mandatory provision for physical activity in new housing developments." The Ministry of Health, which completed the grid, had not been aware of that.

One country was quite an outlier, where two indicators were downgraded from "in place" to "partial" and for two other "in place" indicators were downgraded to "missing," as there was no evidence from any of the 2015 case study stakeholders to support the 2014 self-report responses.

Table 3 shows the agreement (weighted kappa scores) between the indicators that the NCD focal points had reported as having been met when they completed the grid in 2014 and the indicators assessed as having been met based on the in-depth stakeholder interviews in 2015. With the exception of physical activity, agreement was good to excellent for all the clusters of the grid and for the grid as a whole. However, the confidence intervals are wide, reflecting the small sample size, and, with the exception of physical activity, are consistent with poor or fair agreement through excellent agreement. For the physical activity cluster of the grid, confidence intervals are consistent with no agreement through to good agreement.

\section{DISCUSSION}

The annual monitoring grid for 20082015 had relied on self-reported data from the ministries of health, without objective validation of the reports. Self-reports may not align with objective measures (8-10). However, our analysis determined that, overall, the monitoring grid provided an accurate assessment of the national situation, with $95.1 \%$ of reports assessed as being accurate. However, due to a small sample size, the kappa statistic had wide confidence intervals.

The inaccuracies were almost exclusively overreporting of achievements. These findings have validated the self-reported annual monitoring grid, and have shown objectively that self-reports on progress on implementation of NCD policies and programs are a valid methodology for assessing country compliance.

Around the world, the importance of monitoring NCD performance is recognized $(11,12)$. The literature shows NCD policy evaluation in several countries, and other countries rely on policy analysis (13-14).

In West Africa, an assessment by Sodjinou et al. (15) of nutrition programs used a conceptual model that included four levels: 1) tools; 2) skills; 3) staff and infrastructure; and 4) structures, systems, and roles. That research assessed capacity, assets, and gaps at the individual, organizational, and system levels through interviews with key informants from government, development partners, tertiary training institutions, and health professional schools, and then compared the results across countries.

Small island developing states (SIDS), which are primarily located in the Pacific and the Caribbean, share many characteristics, including a high burden of NCDs and their risk factors (16-18).

In the Caribbean and the Pacific, small populations and resultant suboptimal capacity require tailored solutions for monitoring the NCD agenda (19-22).

Like their Caribbean counterparts, the Pacific islands have been monitoring and assessing accountability for 
their responses to the NCD crisis. The Pacific Monitoring Alliance for NCD Action (MANA) simply monitors and records components of NCD country process and outcome indicators (mortality, morbidity, risk factors, health system responses, environments, and policies) captured in a dashboard to demonstrate national and regional progress towards agreed NCD policies and actions. However, the publications do not indicate that any secondary validation process is employed in the $\mathrm{Pa}$ cific $(23,24)$.

This paper goes beyond the initial monitoring and evaluation by validating the Port-of-Spain Declaration grid. It is important to use a method that ideally avoids the same types of potential errors that the completion of the grid has. Similar approaches, such as using another checklist-type questionnaire, would be a poor method of validation. Using in-depth stakeholder interviews, from a range of stakeholders in each country, is a very different methodological approach.

In the peer-reviewed literature, we were not able to identify NCD programs with post-hoc validation of results. Other generic approaches might have been taken to the "validation" of the grid responses.

Baisch et al. (2016) used a qualitative study to compare the "state of the art" and the "state of the practice" and identify the gap between the two (25). Our validation compared the mandates with the practice.

Zhao et al. (26) used experts to conduct a two-round Delphi study and developed a quality assessment index framework for public health services, which was unified and hierarchical. That model is being further tested. While this method focuses on quality of services, it could probably be adapted to evaluate implementation of quality services.

\section{Limitations}

Our in-depth interviews were not specifically designed to validate the grid, but we believe them to potentially give a fuller and more complete picture than one individual (even a well-informed individual) completing the grid.

The kappa statistic takes into account the possibility of similar answers based on chance agreement, and the values have this range: $\leq 0$ (no agreement),
$0.01-0.20$ (none to slight), $0.21-0.40$ (fair), 0.41-0.60 (moderate), 0.61-0.80 (substantial), and 0.81-1.00 (almost perfect). One criticism is that in this ranking, a kappa score of 0.61 is deemed to be substantial agreement, despite there being little agreement among raters. Health-related studies may need to use a higher threshold for acceptable agreement between raters. McHugh suggested that both kappa and percent agreement should be reported (26).

The kappa results are often used to reduce the estimate of agreement, but because the method of utilizing marginal sums may not be reliable, the kappa may not be representative of the amount of rater agreement caused by chance. This is because the assumptions underlying the calculations have not been met, the raters guessed the answer to each item similar to the marginal proportions, or the raters were entirely independent (26).

A further limitation is that kappa is dependent on prevalence and is unable to determine the type or source of disagreement (27). Our small sample size resulted in large confidence intervals, known to be a characteristic of small studies. It is recommended that a Kappa study should have at least 30 comparisons (26).

\section{6 revision of the grid}

The overarching goal of surveillance of country implementation of the Port-ofSpain NCD summit mandates is to provide a "snapshot" of government responses to NCDs. This is a prerequisite to identifying performance by country and across the region to monitor progress, and to influence policy, given that policy reforms will be necessary to achieve the NCD agenda (28).

While the evaluation grid has proved very useful, and indeed is proving of international interest, it also has limitations that need correcting. In addition, some indicators are no longer needed and others need to be added. The original format of the grid was refined and used for the eight years of 2008 through 2015. Table 2 displays the 26 indicators. The work reported here, on the validity of the original format, was used to help update the grid in 2016, when a revised version of the grid with 50 indicators was piloted and introduced.

The first draft of the revised grid came out of discussions at a surveillance workshop in October 2015. A draft was prepared by author TAS and circulated for comments. Then the amended draft was circulated to countries for their comments. Finally, two conference calls were held with countries, at which time they made further edits and they were assisted with filling out the new grid for the first time. Seventeen of 20 countries submitted in 2016, and 19 of 20 did so by 2017, with Haiti being the only country with no response and all indicators missing (Table 4).

The features of the revised grid include 50 indicators (up from the previous 26 indicators). These include: 1) indicators from the 2016 Heads of Government communiqué on NCDs; 2) standardized questions to identify performance; 3) questions from the WHO country capacity survey; 4) indicators from the Framework Convention on Tobacco Control (FCTC); and 5) PAHO or WHO process indicators. For the countries, use of these standardized indicators reduces duplication of reporting efforts. Indicators on alcohol-related harm were added, although this is not part of the Port-of-Spain Declaration.

The indicator on ratification of the FCTC in the version of the grid used in 2008-2015 was dropped in the 2016 revision, since all the independent countries, with the exception of Haiti, have ratified the FCTC. Instead, the four specific FCTC commitment indicators were included, utilizing FCTC language and definitions.

\section{Burden of NCD reporting}

As part of the evaluation of the Portof-Spain NCD Declaration that was carried out by a consortium of researchers, led by the University of the West Indies, in 2014-2017, a 2016 audit was done by author TAS of routine, periodic NCD reporting that regional and international health organizations require from all countries in the Caribbean Community. Those requirements included: a) 3 reports to be made annually (including reporting on the annual evaluation grid); b) 12 reports every two or three years; and c) 2 reports and 5 population-based surveys every five years. That is a total of 22 reports (Table 5).

In addition, there were 3 more reports being developed or being pilottested as of 2015: 1) a disability survey 


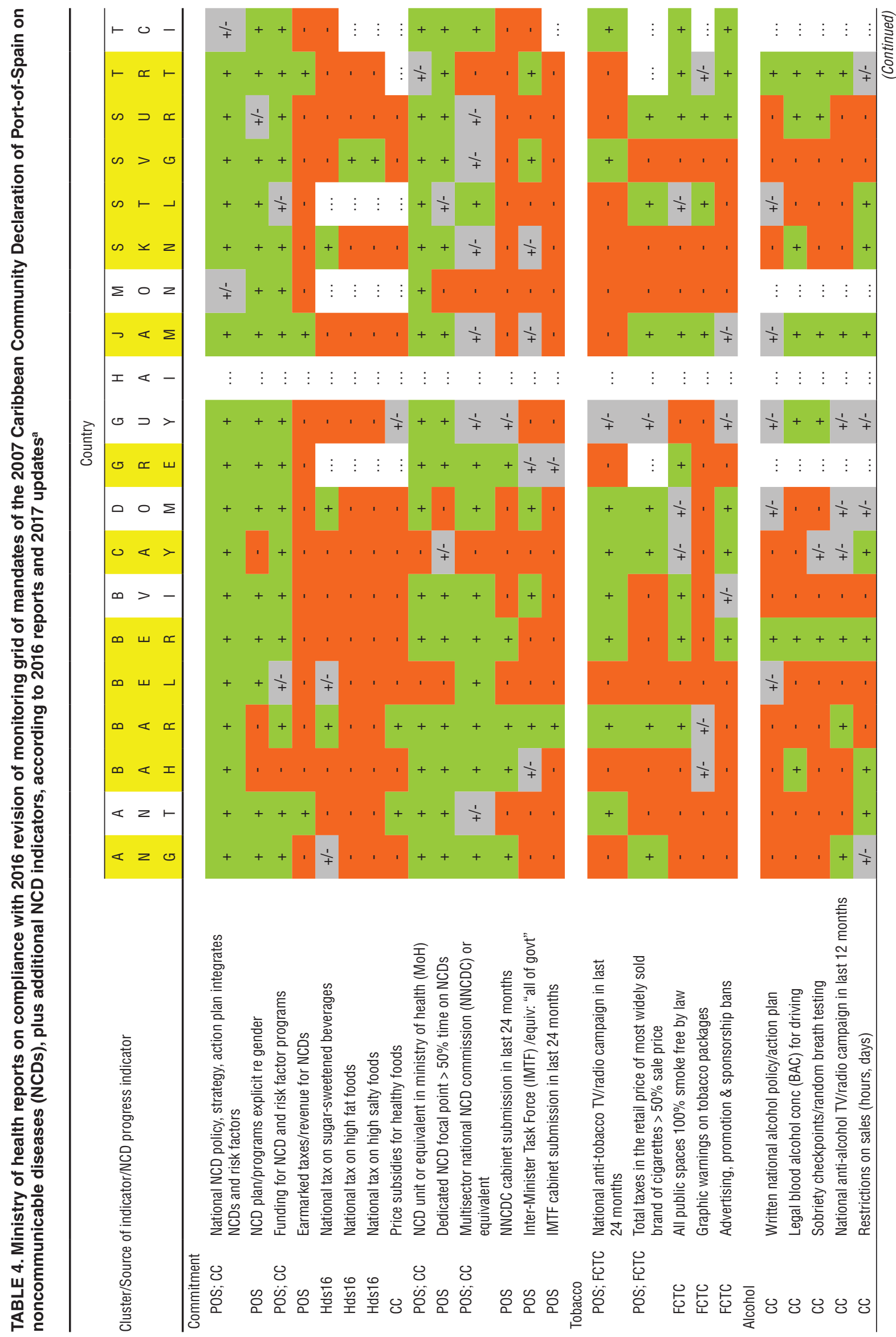




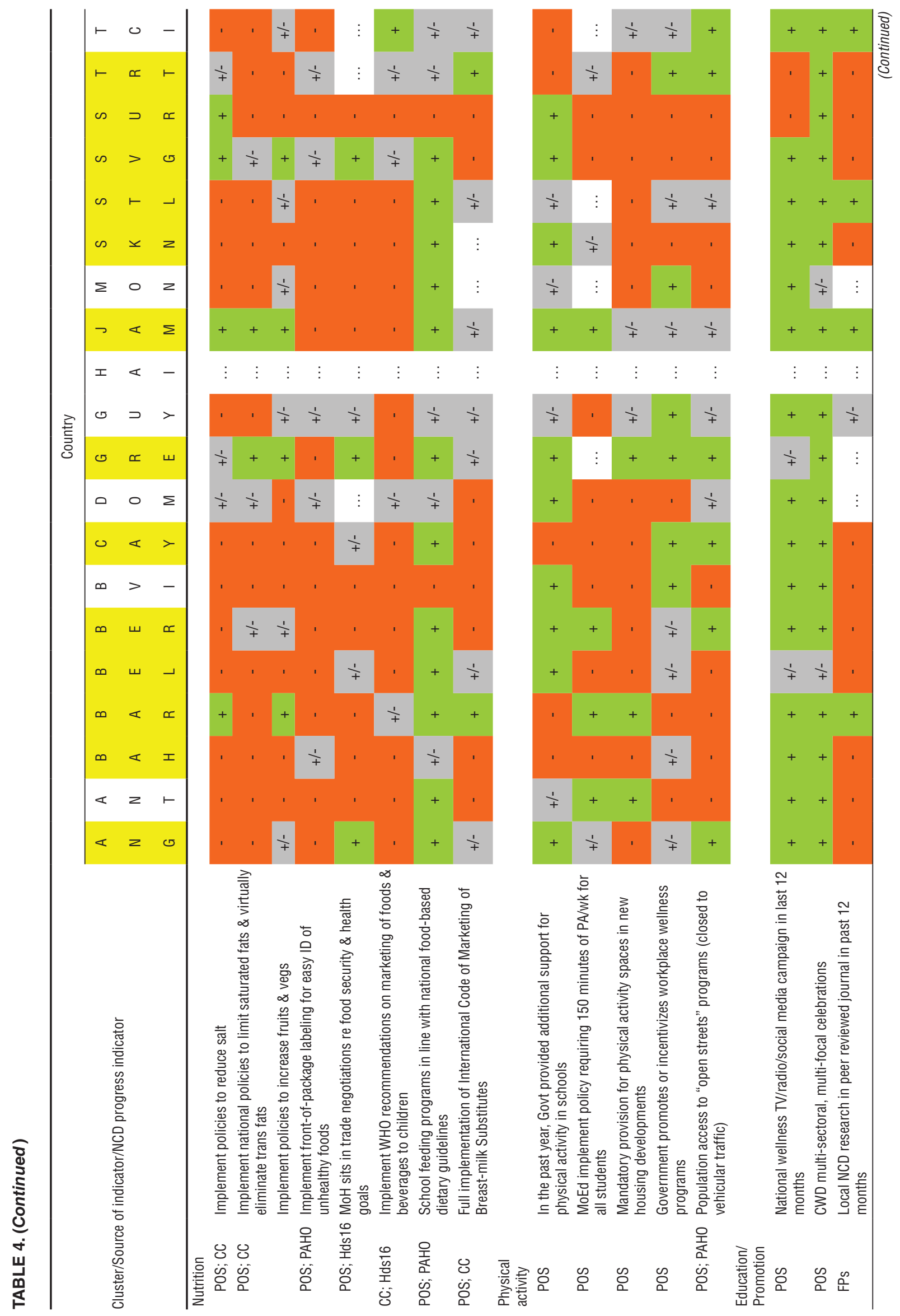




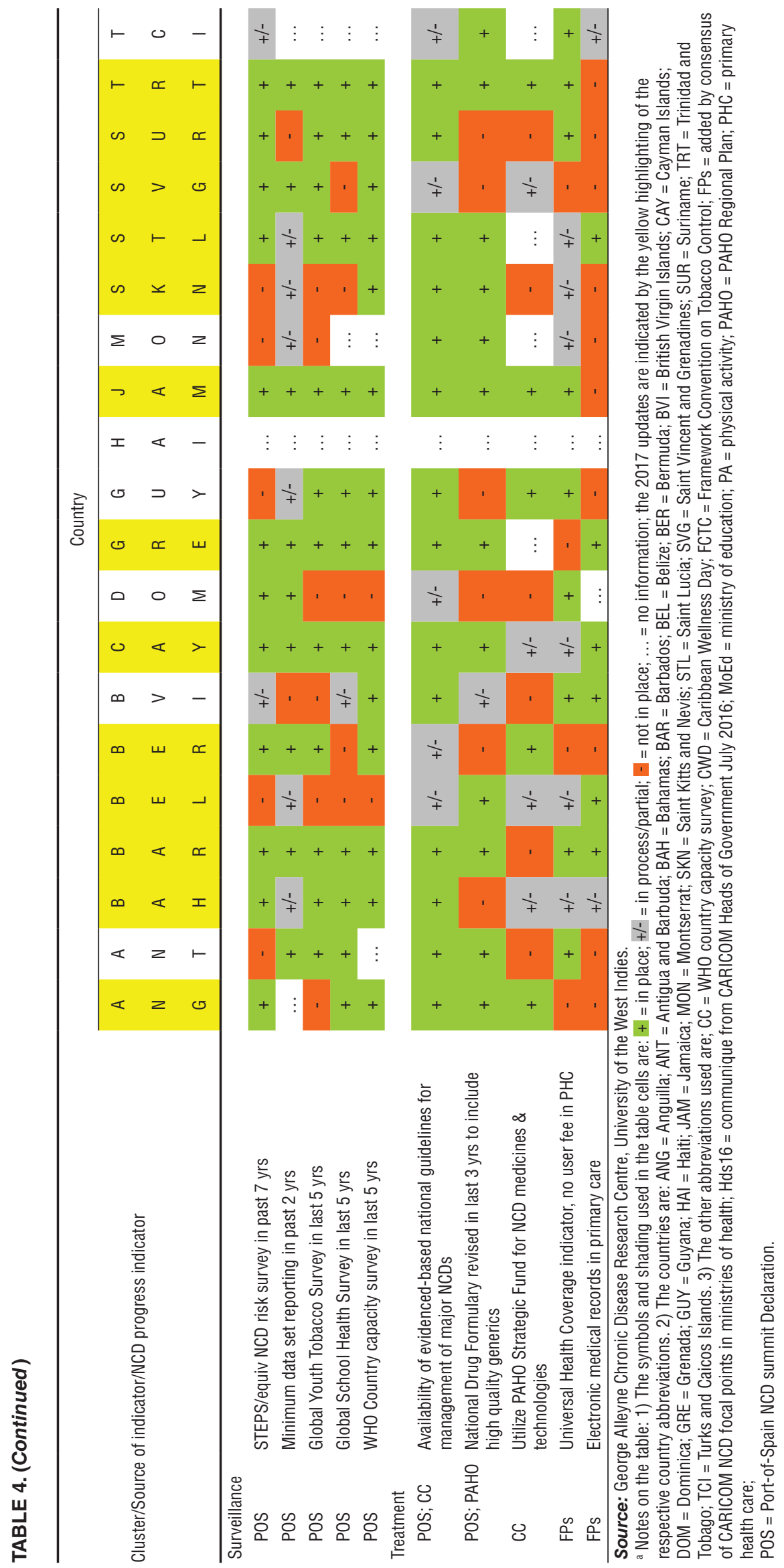


TABLE 5. Reporting on noncommunicable diseases (NCDs) required of Caribbean Community countries by the Pan American Health Organization (PAHO), World Health Organization (WHO), Caribbean Public Health Agency (CARPHA), and University of the West Indies (UWI) annually or every two, three, or five years, as identified in 2015

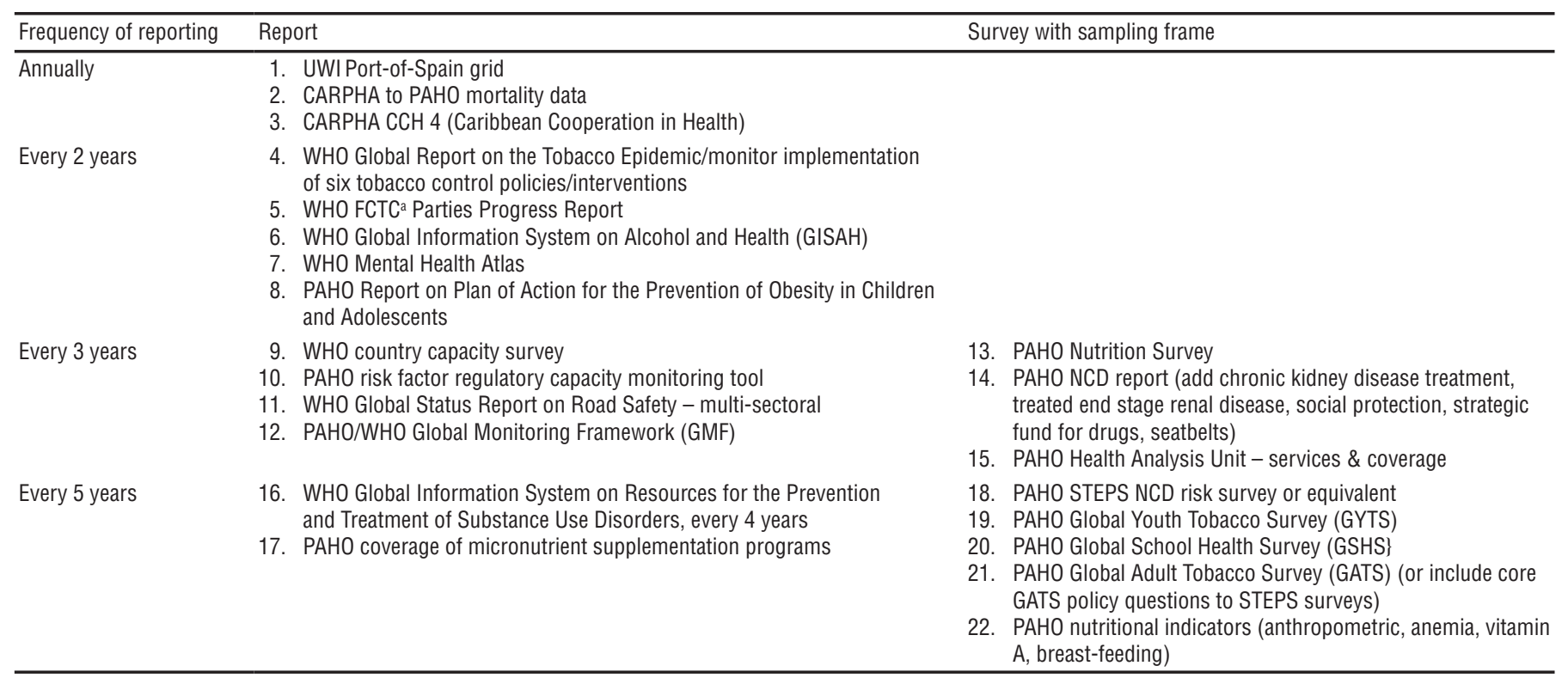

Source: Study research by author TAS.

${ }^{\mathrm{a}} \mathrm{FCTC}=$ Framework Convention on Tobacco Control.

to estimate the prevalence of disability within the population; 2) a risk factor (RF) regulatory-capacity monitoring tool to assess country capacity to regulate risk factors; and 3) the Mapping Instrument for NCDs/RFs Surveillance (MAPI), which is a PAHO tool to assess a country's capacity to conduct mortality and risk factor surveillance.

PAHO or WHO require 19 of these 22 reports, which have been developed in response to global and/or regional commitments that PAHO Member States have made. However, due to the small size of many Caribbean countries and territories, and therefore, the small size of their ministries of health, this extensive NCD reporting is a burden. The reporting demands on small island developing states with limited numbers of staff for their small populations is the same as the reporting requirements for large countries. A review of these requirements (especially by $\mathrm{PAHO}$ and $\mathrm{WHO}$ ) might identify a core set of reports, and within them, a core set of questions that could form a minimum data set for reporting from countries with limited human resources..

\section{Conclusions}

Despite a heavy burden of required NCD reports, CARICOM countries have invested in and supported annual reporting of the indicators of the Port-ofSpain NCD Declaration. During the 2016 revision, country NCD focal points were actively involved in determining which indicators they wished to report, and in insisting that alcohol-harm indicators be added, although this was not addressed in the 2007 Declaration nor in the 20082015 version of the grid. The development, validation, revision, and uptake of the new, 2016 version of the grid indicate country support for this process.

This article validates country self-reports of the Port-of-Spain NCD Declaration progress indicators by using the seven country case studies, which collected objective data to compare with the self-reports. This piece also reports on the process and outcome of the 2016 revision of the grid. This article therefore is likely to contribute to the discourse around methodology and validity of middle-income, small island states with limited human resources. The piece also highlights the burden of reporting for small island developing states, including reporting on the WHO NCD Global Monitoring Framework.

Acknowledgments. We express our thanks to the NCD focal points and the chief medical officers in CARICOM member states who completed their country grids each year, as well as the Port-of-Spain NCD Declaration evaluation team who contributed to the revision of the grid in 2016.

Funding. This work was carried out with the aid of a grant from the International Development Research Centre, Ottawa, Canada.

Conflicts of interest. None declared.

Disclaimer. Authors hold sole responsibility for the views expressed in the manuscript, which may not necessarily reflect the opinion or policy of the RPSP/ PAJPH or PAHO. 


\section{REFERENCES}

1. Lencucha R, Dube L, Blouin C, Hennis A, Pardon M, Drager N. Fostering the catalyst role of government in advancing healthy food environments. Int J Health Policy Manag. 2018;7(6): 485-90.

2. Nugent R, Bertram MY, Jan S, Niessen LW, Sassi F, Jamison DT, et al. Investing in non-communicable disease prevention and management to advance the Sustainable Development Goals. Lancet. 2018;391(10134):2029-35.

3. Hospedales CJ, Samuels TA, Cummings R, Gollop G, Greene E. Raising the priority of chronic noncommunicable diseases in the Caribbean. Rev Panam Salud Publica. 2011;30(4):393-400.

4. Di Ruggiero E, Leung Z, Mwatsama M, Hallen G. Sustainable partnerships for NCD prevention: implications for public health. Int J Public Health. 2018 May 15. doi: $10.1007 / \mathrm{s} 00038-018-1112-8$.

5. Murray CJL. Choosing indicators for the health-related SDG targets. Lancet. 2015;386(10001):1314-7.

6. Samuels TA, Unwin N, eds. The evaluation of the 2007 CARICOM Heads of Government Port of Spain NCD Summit Declaration. The investigators' detailed report. Available from: http:// onecaribbeanhealth.org/wp-content/ uploads /2018/01/POSDEVAL_TheInvestigators-report_FINAL.pdf Accessed 10 October 2018.

7. Samuels TA, Kirton J, Guebert J. Monitoring compliance with high-level commitments in health: the case of the CARICOM summit on chronic non-communicable diseases. Bull World Health Organ. 2014;92(4):270-6b.

8. Tolonen H, Koponen P, Mindell JS, Mannisto S, Giampaoli S, Dias CM, et al. Under-estimation of obesity, hypertension and high cholesterol by self-reported data: comparison of self-reported information and objective measures from health examination surveys. Eur J Public Health. 2014;24(6):941-8.

9. Howitt C, Brage S, Hambleton IR, Westgate K, Samuels TA, Rose AM, et al. A cross-sectional study of physical activity and sedentary behaviours in a Caribbean population: combining objective and questionnaire data to guide future interventions. BMC Public Health. 2016;16(1):1036.
10. McLennan AK, Shimonovich M, Ulijaszek SJ, Wilson M. The problem with relying on dietary surveys: sociocultural correctives to theories of dietary change in the Pacific islands. Ann Hum Biol. 2018;45(3):272-84.

11. Bell E, Tappero JW, Ijaz K, Bartee M, Fernandez J, Burris $\mathrm{H}$, et al. Joint external evaluation-development and scale-up of global multisectoral health capacity evaluation process. Emerg Infect Dis. 2017;23(13).

12. Tangcharoensathien V, Srisookwatana O, Pinprateep P, Posayanonda T, Patcharanarumol W. Multisectoral actions for health: challenges and opportunities in complex policy environments. Int J Health Policy Manag. 2017;6(7):359-63.

13. Biswas T, Pervin S, Tanim MIA, Niessen L, Islam A. Bangladesh policy on prevention and control of non-communicable diseases: a policy analysis. BMC Public Health. 2017;17(1):582.

14. Mukanu MM, Zulu JM, Mweemba C, Mutale W. Responding to noncommunicable diseases in Zambia: a policy analysis. Health Res Policy Syst. 2017;15(1):34.

15. Sodjinou R, Bosu WK, Fanou N, Deart L, Kupka R, Tchibindat F, et al. A systematic assessment of the current capacity to act in nutrition in West Africa: cross-country similarities and differences. Glob Health Action. 2014;7:24763.

16. Kessaram T, McKenzie J, Girin N, Roth A, Vivili P, Williams G, et al. Noncommunicable diseases and risk factors in adult populations of several Pacific islands: results from the WHO STEPwise approach to surveillance. Aust N Z J Public Health. 2015;39(4):336-43.

17. Hawley NL, McGarvey ST. Obesity and diabetes in Pacific Islanders: the current burden and the need for urgent action. Curr Diab Rep. 2015;15(5):29.

18. Sobers-Grannum N, Murphy MM, Nielsen A, Guell C, Samuels TA, Bishop L, et al. Female gender is a social determinant of diabetes in the Caribbean: a systematic review and meta-analysis. PLoS One. 2015;10(5):e0126799.

19. Gouda HN, Richards NC, Beaglehole R, Bonita R, Lopez AD. Health information priorities for more effective implementation and monitoring of non-communicable disease programs in low- and middle-income countries: lessons from the Pacific. BMC Med. 2015;13:233.

20. Hosey GM, Rengiil A, Maddison R, Agapito AU, Lippwe K, Wally OD, et al. U.S. Associated Pacific Islands health care teams chart a course for improved health systems: implementation and evaluation of a non-communicable disease collaborative model. J Health Care Poor Underserved. 2016;27(4a):19-38.

21. Rose AM, Hambleton IR, Jeyaseelan SM, Howitt C, Harewood R, Campbell J, et al. Establishing national noncommunicable disease surveillance in a developing country: a model for small island nations. Rev Panam Salud Publica. 2016;39(2):76-85.

22. Guariguata L, Guell C, Samuels TA, Rouwette EA, Woodcock J, Hambleton IR, et al. Systems science for Caribbean health: the development and piloting of a model for guiding policy on diabetes in the Caribbean. Health Res Policy Syst. 2016;14(1):79.

23. Tolley H, Snowdon W, Wate J, Durand AM, Vivili P, McCool J, et al. Monitoring and accountability for the Pacific response to the non-communicable diseases crisis. BMC Public Health. 2016; 16:958.

24. Ekeroma A. Collaboration as a tool for building research capacity in the Pacific Islands. Ann Hum Biol. 2018;45(3):295-6.

25. Baisch BA, Krajny S, Wagner LM, Symons CW. A qualitative analysis of health education practice in applied work settings. Health Promot Pract. 2016;17(6):899-906.

26. McHugh ML. Interrater reliability: the kappa statistic. Biochemia Med. 2012;22(3):276-82.

27. Viera AJ, Garrett JM. Understanding interobserver agreement: the kappa statistic. Fam Med. 2005;37(5):360-3.

28. Mendis S, Chestnov O. Policy reform to realize the commitments of the Political Declaration on noncommunicable diseases. Br Med Bull. 2013;105:7-27.

Manuscript received on 17 May 2018. Revised version accepted for publication on 30 July 2018. 
RESUMEN Objetivos. En el 2007, la Comunidad del Caribe (CARICOM) convocó su primera cumbre de jefes de Gobierno sobre enfermedades no transmisibles (ENT) y emitió una declaración sin precedentes, la Declaración de Puerto España: Unidos para detener la epide-

Validación de la matriz de autonotificación anual para el seguimiento de la Declaración de Puerto España sobre enfermedades no transmisibles de la Comunidad del Caribe mia de enfermedades crónicas no transmisibles. Desde entonces, los puntos focales de los ministerios de salud cada año usan una matriz con 26 indicadores a fin de autonotificar las actividades que ha realizado el país en el ámbito de las ENT. Nuestro objetivo fue evaluar la validez de las respuestas dadas en la matriz, creada para evaluar la ejecución de la Declaración de Puerto España, comparándolas con la información obtenida en entrevistas exhaustivas y la revisión de documentos.

Métodos. En el 2015 se llevaron a cabo siete estudios de casos a nivel de país sobre las respuestas a la Declaración en el ámbito de políticas. Se realizaron entrevistas exhaustivas y semiestructuradas con interesados directos de múltiples sectores, incluidos los ministerios de salud. Además, se definieron y examinaron documentos de políticas. Los resultados de los estudios de casos del 2015 se compararon con las respuestas que los puntos focales de los ministerios de salud dieron en las matrices del 2014. Se usó el coeficiente kappa para evaluar el grado de concordancia.

Resultados. Hubo un alto grado de concordancia entre la información de la matriz y la de los estudios de casos. De un total de 182 indicadores (26 de cada uno de los siete países), hubo diferencias en solo 9 casos (4,9\%), y todas las diferencias se encontraron entre las declaraciones de política y la ejecución. Salvo en el caso de la actividad física, el coeficiente kappa indicó que la concordancia fluctuó entre aceptable y excelente en todas las secciones de la matriz que agrupan a los indicadores y la cuadrícula en general, pero con intervalos de confianza amplios.

Conclusiones. En general, la matriz utilizada para el seguimiento de la Declaración evaluó con exactitud la situación nacional, pero se observó una posible tendencia a sobrevalorar el desempeño en algunos campos. Estos resultados fueron útiles en el 2016 cuando se diseñó una nueva matriz de seguimiento con 50 indicadores. A pesar de estas mejoras, los países de CARICOM siguen enfrentando una carga sustancial al tener que realizar muchos otros informes sobre las ENT, principalmente para la Organización Panamericana de la Salud y la Organización Mundial de la Salud.

Palabras clave Enfermedades no transmisibles; vigilancia en salud pública; Indias Occidentales. 
RESUMO Objetivos. A Comunidade do Caribe (CARICOM) realizou em 2007 a Primeira Cúpula dos Chefes de Governos sobre Doenças Não Transmissíveis (DNTs) que culminou com a inédita Declaração de Porto de Espanha: Unidos para Deter a Epidemia

Validação da matriz autorrelatada de monitoramento anual da Declaração de Porto de Espanha de 2007 da Comunidade do Caribe em doenças não transmissíveis de DNTs Crônicas. Desde então, as coordenações dos ministérios da Saúde de cada país apresentam anualmente um informe autorrelatado dos esforços para combater as DNTs usando uma matriz com 26 indicadores criada para avaliar a implementação da Declaração. Nosso objetivo foi avaliar a validade dos dados contidos na matriz comparadas à informação obtida em entrevistas aprofundadas e análises de documentos. Métodos. Foram realizados em 2015 sete estudos de caso nacionais das medidas de políticas tomadas em resposta à Declaração. Foram conduzidas entrevistas aprofundadas e semiestruturadas com os interessados diretos de vários setores, inclusive com o pessoal dos ministérios da Saúde. Documentos de políticas também foram selecionados e examinados. Os resultados dos estudos de caso de 2015 foram comparados aos dados fornecidos na matriz de 2014 pelos coordenadores dos ministérios da Saúde. O coeficiente de concordância de kappa foi usado para avaliar a concordância esperada pelo acaso.

Resultados. Os dados da matriz e dos estudos de caso tiveram uma estreita concordância. Dos 182 indicadores ao todo (26 para cada um dos sete países), houve ausência de concordância em apenas $9(4,9 \%)$. Todas as diferenças foram entre declarações de políticas e implementação. Exceto para atividade física, o coeficiente kappa indicou concordância boa a excelente para todos os clusters da matriz e para a matriz como um todo, porém com intervalos de confiança amplos.

Conclusões. A matriz de monitoramento proporcionou uma avaliação precisa da conjuntura nacional, porém com uma possível tendência de atribuir um desempenho melhor em algumas áreas. Esses resultados contribuíram para a elaboração em 2016 de uma nova matriz de monitoramento contendo 50 indicadores. Apesar dessas melhorias, os países da CARICOM ainda enfrentam uma enorme obrigação em ter de preencher muitos outros informes de DNTs, sobretudo para a Organização PanAmericana da Saúde e a Organização Mundial da Saúde.

Palavras-chave Doenças não transmissíveis; vigilância em saúde pública; Índias Ocidentais. 